\title{
Effect of Soil Contamination on the Mineral Composition of Forage Fertilized with Nitrogen
}

\author{
H.F. MAYLAND AND F.A. SNEVA
}

\begin{abstract}
Mineral analysis of forage from a nitrogen $(N)$ fertilizer, field study produced unexpectedly high iron $(\mathrm{Fe})$ concentrations which were correlated with the $N$ fertilizer level $\left(r^{2}=.92\right)$ and the percentage $\mathrm{N}$ in the forage $\left(r^{2}=.94\right)$. The high $\mathrm{Fe}$ values were presumed to be associated with dust on the leaves. The objective of this study was to determine the level of soil contamination on the forage sample and the contribution of mineral in the contaminant to that measured in the sample. Soil contamination of plant tissue samples was calculated from the dilution of soil titanium (Ti) assuming that the uncontaminated tissue contained $0 \mathrm{~g} \mathrm{Ti} / \mathrm{g}$. Tissue harvested from the $0,28,56$, or $84 \mathrm{~kg} \mathrm{~N} /$ ha treatments contained $23,49,48$, and $60 \mathrm{mg}$ soil $/ \mathrm{g}$, respectively. Significant $\mathrm{N}$ fertilizer effects would have been accepted for each element tested if soil contamination had been ignored. Correcting for contamination resulted in significant $\mathbf{N}$-fertilizer effects on the concentrations of sodium, potassium, manganese, iron, and zinc but not magnesium or calcium in the forage. Some of these effects may be explained by the acidifying effect of the $\mathbf{N}$ fertilizer source.
\end{abstract}

Interest in mineral cycling under semiarid pasture conditions led to the investigation of elemental concentrations in forage that had received annual nitrogen $(\mathrm{N})$ fertilizer applications during a 4-year period. Initial chemical analysis indicated that fertilizer $\mathbf{N}$ increased the concentrations of both $\mathrm{N}$ and iron $(\mathrm{Fe})$ in the forage. Because Fe concentrations exceeded $300 \mu \mathrm{g} / \mathrm{g}$, we suspected that the forage samples were contaminated with soil.

Procedures based on the ability of the plant to descriminate against the uptake of soil aluminum ( $\mathrm{Al}$ ), $\mathrm{Fe}$, and titanium (Ti) have been developed to measure the degree of soil contamination in plant tissue (Healy et al. 1974, Metson et al. 1979, and Nes 1975). Metson et al. assumed that $\mathrm{Fe}$ values of 80,100 , and $100 \mu \mathrm{g} / \mathrm{g}$ for grass, clover, and other herbage, respectively, were threshold concentrations between endogenous (absorbed internally by the plant) and exogenous (external as dust) $\mathrm{Fe}$. They also assumed that threshold concentrations of $\mathrm{Al}$ were 70,100 , and $120 \mu \mathrm{g} / \mathrm{g}$ for grass, clover, or other herbage, respectively. In each case forage mineral concentrations were corrected for soil contamination based upon these threshold values of Fe or Al. They found reasonable agreement between the two estimates, although in some instances the amount of soil contamination estimated from the $\mathrm{Fe}$ values was considerably higher than that derived from the Al data.

Nes (1975) reported good correlations between sample ash and Ti concentrations when plant samples were contaminated with known amounts of soil. Metson et al. (1979) reported good agreement in calculated contamination levels when using the $\mathrm{Ti}, \mathrm{Al}$, or Fe discrimination technique. However, a limited number of samples were used in the latter study.

Titanium might provide a highly sensitive measure of soil contamination because of its low concentration, less than $3 \mu \mathrm{g} / \mathrm{g}$, in

\footnotetext{
Authors are with the USDA, Agricultural Research Service, Kimberly, Ida. 83341 and Burns, Ore. 97720 , respectively.

Manuscript received May 5, 1982.
}

plants and the large discrimination factor of 10,000 to 500,000 between the concentration in soils and in plants (Mitchell 1960 and Shacklette 1980). These discrimination values are compared with values of 500 to 3000 for $\mathrm{Fe}$ and 1000 to 5000 for $\mathrm{Al}$ (Mitchell 1960 and Shacklette 1980). This advantage for Ti, however, is valid only if the analytical sensitivity is similar for each of the elements.

The objectives of this study were to utilize the Ti method to measure the level of soil contamination, to identify endogenous levels of elements measured in plant tissue, and to determine the real effect of $\mathbf{N}$ fertilization on endogenous mineral concentrations in the forage tissue. Previous authors have given little detail to the methodology. Therefore, additional discussion is directed to the mineral dilution technique as a means to calculate endogenous mineral values.

\section{Methods and Procedure}

The experiment was conducted on a previously established field of crested wheatgrass (Agropyron desertorum (Fisch. ex Link) Schult.) located on a sandy loam xerollic camborthid soil on the Squaw Butte Experiment Station near Burns, Ore. The experiment consisted of a randomized block design with 3 replications. The plots were fertilized each autumn for 4 years with $0,28,56$ or $84 \mathrm{~kg}$ $\mathrm{N} / \mathrm{ha}$ as ammonium nitrate $\left(\mathrm{NH}_{4} \mathrm{NO}_{3}\right)$. The fourth year's growth was hand clipped at a $3-\mathrm{cm}$ stubble height in mid summer, dried at $55^{\circ} \mathrm{C}$, ground to pass through a $1-\mathrm{mm}$ sieve, and stored over phosphorus pentoxide $\left(\mathrm{P}_{2} \mathrm{O}_{5}\right)$ desiccant. Samples were analyzed for total $\mathrm{N}$ by the Kjeldahl procedure which was modified to include nitrate. Mineral concentrations were determined by atomic absorption with either flame or flameless (for Ti only) atomization of samples previously digested in a 3:1 mixture of nitric:perchloric acid $\left(\mathrm{HNO}_{3}: \mathrm{HClO}_{4}\right)$ and appropriately diluted. Methods of soil $(<100 \mu \mathrm{m})$ or titanium dioxide $\left(\mathrm{TiO}_{2}\right)$ additions to forage samples produced linear responses $\left(r^{2}=.99\right)$ to Ti measured in the 0 to 500 $\mu \mathrm{g} / \mathrm{g}$ range. The coefficient of variation of these analyses was about $5 \%$.

Soil $\mathrm{pH}$ was determined on a saturated paste of a composite sample taken from 0 to $15-\mathrm{cm}$ depth in each plot. A composite soil sample, collected from the 0 to $1-\mathrm{cm}$ depth and passing through a $100-\mathrm{m}$ sieve, was dry ashed at $550^{\circ} \mathrm{C}$ overnight and then digested with $\mathrm{HNO}_{3}: \mathrm{HClO}_{4}(3: 1)$ prior to elemental analysis. The soil concentration of the tissue samples was determined from the dilution of soil $\mathrm{Ti}$ or $\mathrm{Fe}$ assuming 0 or $80 \mu \mathrm{g} / \mathrm{g}$ endogenous $\mathrm{Ti}$ or $\mathrm{Fe}$ in the plant, respectively. The endogenous mineral concentration $\left(\mathrm{M}_{\mathrm{e}}\right)$ in the forage was calculated as follows:

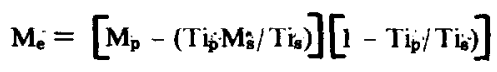

where $\mathrm{M}_{\hat{\mathrm{p}}}$ and $\mathrm{M}_{\hat{\mathrm{s}}}$ were the mineral concentrations in the plant and soil sample, respectively, and $\mathrm{Ti} \hat{p}$ and $\mathrm{Ti} \hat{s}$ were the Ti concentrations in the plant and soil samples, respectively. For the Fe procedure, soil Fe concentration was substituted for $\mathrm{Ti}_{\hat{8}}$ and plant $\mathrm{Fe}$ 
Table 1. Mean mineral concentrations in soil and forage, the ratio of the mineral concentration in soil to that endogenous in the plant (calculated by the titanium dilution technique) and the endogenous mineral concentration in forage fertilized with four rates of $\mathbf{N}$.

\begin{tabular}{|c|c|c|c|c|c|c|c|c|}
\hline \multirow[b]{2}{*}{ Mineral } & \multirow{2}{*}{$\begin{array}{l}\text { Conc. in } \\
\text { soil }\end{array}$} & \multicolumn{2}{|c|}{ Conc. in forage } & \multirow{2}{*}{$\begin{array}{c}\text { Mineral } \\
\text { ratio }\end{array}$} & \multicolumn{4}{|c|}{ Endogenous mineral conc. for each fertilizer $\mathrm{N}$ rate $(\mathrm{kg} / \mathrm{ha})$} \\
\hline & & Apparent & Endogenous & & 0 & 28 & 56 & 84 \\
\hline & \multicolumn{4}{|c|}{$-\mu \mathrm{g} / \mathrm{g}-$} & \multicolumn{4}{|c|}{$-\mu \mathrm{g} / \mathrm{g}-$} \\
\hline $\mathrm{Na}$ & 1,630 & 93 & 30 & 54 & 47 & 22 & 24 & 26 \\
\hline $\mathbf{K}$ & 18,200 & 10,900 & 10,600 & 2 & 8,900 & 10,600 & 11,800 & 11,100 \\
\hline $\mathbf{M g}_{\mathbf{g}}$ & 17,000 & 1,840 & 1,110 & 15 & \multicolumn{4}{|c|}{ not significant } \\
\hline $\mathrm{Ca}$ & 55,000 & 4,400 & 2,000 & 28 & \multicolumn{4}{|c|}{ not significant } \\
\hline Mn & 390 & 63 & 47 & 8 & 32 & 47 & 50 & 60 \\
\hline $\mathrm{Fe}$ & 16,300 & 861 & 123 & 132 & 62 & 59 & 163 & 209 \\
\hline $\mathrm{Zn}$ & 29 & 18 & 17 & 2 & 13 & 18 & 19 & 20 \\
\hline $\mathrm{Ti}$ & 4,785 & 218 & 0 & $>4785$ & & & & \\
\hline
\end{tabular}

concentration minus $80 \mu \mathrm{g} / \mathrm{g}$ was substituted for $\mathrm{Ti}_{\mathrm{p}}$.

Data were analyzed by analysis of variance and the effects of $\mathrm{N}$ fertilization on the factors under consideration were partitioned into linear and quadratic components.

\section{Results and Discussion}

Forage samples were processed and analyzed for various elements. Data from these initial analyses were identified as apparent concentrations because they were not adjusted or corrected for the effects of soil contamination. The apparent concentration means across all $\mathbf{N}$ treatments are shown in Table 1. Analysis of variance of these data indicated significant $[P<.01$ for magnesium $(\mathrm{Mg})$, Calcium (Ca), Fe, and zinc $(\mathrm{Zn})$ and $P<.05$ for sodium (Na), potassium (K), manganese (Mn), and Ti] effects of fertilizer $\mathrm{N}$ on mineral concentrations in forage (not shown). The response to fertilizer $N$ rates was linear $(P<.01)$ for each element while the quadratic was significant $(P<.05)$ only for $\mathrm{K}$ and $\mathrm{Zn}$.

Forage Fe concentrations (not shown) were positively correlated with both $\mathrm{N}$ fertilization rate $\left(r^{2}=.92\right)$ and forage- $\mathrm{N}$ concentrations $\left(r^{2}=.94\right)$. It was not known whether this occurred because of (1) $\mathrm{N}$-enhanced plant nutrition, (2) fertilizer $\mathrm{N}$ decreased soil $\mathrm{pH}$ and increased mineral availability and uptake by plants or (3) soil contamination. The positive correlation $\left(r^{2}=.98\right)$ between $\mathrm{Fe}$ and Ti suggested that soil contamination may have biased the apparent mineral concentration data.

Soil contamination and apparent mineral concentration data were next corrected by the Ti dilution technique. Soil contamination was calculated as $23,49,48$, and $60 \mathrm{mg} / \mathrm{g}$ of sample for the 0 , 28,56 , and $84 \mathrm{~kg} \mathrm{~N} /$ ha fertilizer treatments, respectively. Mean values for the corrected mineral data, hereafter called endogenous values, are shown in Table 1 for each $\mathbf{N}$ treatment and across all $\mathbf{N}$ treatments.

Analysis of variance of the endogenous data indicated significant $(P<.01$ for $\mathrm{Fe}$ and $\mathrm{Zn}$ and $P<.05$ for $\mathrm{Na}, \mathrm{K}$ and $\mathrm{Mn})$ effects of fertilizer $N$ on forage mineral concentrations. The response to fertilizer rates (Table 1) was significantly linear $(P<.01$ for $\mathrm{Mn}, \mathrm{Fe}$, and $\mathrm{Zn}$ and $P<.05$ for $\mathrm{Na}$ and $\mathrm{K}$ ) for these minerals whereas the quadratic was significant $(P<.05)$ for $\mathrm{N}$ and $\mathrm{Zn}$. Fertilization had no effect on endogenous $\mathrm{Mg}$ and $\mathrm{Ca}$ concentrations.

The analysis of variance was also used to measure the importance of correcting forage mineral values for soil contamination. The corrected, or endogenous values, were significantly different $(P<.01$ ) from the apparent values for $\mathrm{Na}, \mathrm{Mg}, \mathrm{Ca}, \mathrm{Mn}$, and $\mathrm{Fe}$, but not different $(P<.01)$ for $\mathrm{K}$ or $\mathrm{Zn}$ values.

Endogenous mineral values calculated by the Ti procedure were compared with those calculated by the Fe procedure. The endogenous mineral concentrations were not different $(P<.2)$ when the two procedures were compared. Forage Fe values calculated by the two procedures would not be compared because all values were set at 80 $\mu \mathrm{g} \mathrm{Fe} / \mathrm{g}$ for the Fe method. The Fe values corrected by the $\mathrm{Ti}$ method (Table 1) were 62,59, 163 and $209 \mu \mathrm{g} / \mathrm{g}$ for the $0,28,56$ and $84 \mathrm{~kg} /$ ha $\mathrm{N}$ fertilizer rates, respectively. This range in endogenous Fe reduces the confidence placed on the assumed endogenous value of $80 \mu \mathrm{g} \mathrm{Fe} / \mathrm{g}$ in grasses.

The reduction in soil $\mathrm{pH}(6.9,6.3,6.1$, and 5.8 at $\mathrm{N}$ rates of 0,28 , 56 , and $84 \mathrm{~kg} / \mathrm{ha}$, respectively) would increase soil-Fe and $\mathrm{Mn}$ solubility and uptake by plants (Hodgson 1963 and Horvath 1972), thus explaining the increase in endogenous forage $\mathrm{Fe}$ and $\mathrm{Mn}$ values with increasing $\mathbf{N}$ fertilization rates (Table 1 ). The $\mathbf{N}$ fertilizer tended to retard morphological development and produced plants with large, thin leaves and larger leaf:stem ratio (Hyder and Sneva 196I). Leaves of the $\mathbf{N}$ fertilized plants were not erect, but folded or bent in a way which positioned them closer to the ground and exposed them to more dust.

\section{Conclusions}

Significant $\mathrm{N}$ fertilizer effects would have been accepted for each element tested if soil contamination, as measured by the Ti dilution technique, had been ignored. Correcting these apparent values for soil contamination still resulted in significant $\mathbf{N}$ fertilizer effects on $\mathrm{Na}, \mathrm{K}, \mathrm{Mn}, \mathrm{Fe}$, and $\mathrm{Zn}$ concentrations, but the effects of $\mathrm{N}$ on forage $\mathrm{Mg}$ and $\mathrm{Ca}$ concentrations were not significant. Calculated values based on the $80 \mu \mathrm{g} / \mathrm{g}$ threshold value for Fe were not different than those based on $0 \mu \mathrm{g} / \mathrm{g}$ for $\mathrm{Ti}$, except that the effect of $\mathrm{N}$ fertilizer increased endogenous Fe concentrations. The effect of soil $\mathrm{pH}$ on forage $\mathrm{Fe}$ uptake would reduce the acceptability of the Fe dilution technique to determine the effect of soil contamination, especially where plants are grown on soils where $\mathrm{pH}$ differs.

The ratio of mineral concentration in soil to that in plant tissue was not as large for $\mathrm{Fe}$ and $\mathrm{Ti}$ as suggested from literature values. This may have occurred because of a lower mineral concentration in this soil or an incomplete recovery by the wet ashing procedure. Nevertheless, concentrations of these two elements were useful when calculating the amount of soil contamination in forage. Soil treatments that alter the concentration of endogenous $\mathrm{Fe}$, or even $\mathrm{Ti}$, in the plant will reduce the accuracy of this procedure.

The concentration of Fe or Ti may vary with soil particle size. Thus the choice of soil particle size that is chosen to represent the dust on the plant sample may be very crucial. Extraction or solubilization of soil and plant samples should use the same procedures to account for similar solubilities in the soil and dust fractions. If the reference soil sample accurately represents the contaminating dust on the forage then the Ti procedure is preferred, because Ti and Fe can be analyzed with equal sensitivity and the Ti method allows measurement of treatment effects on endogenous Fe concentrations in tissue. Both $\mathrm{Fe}$ and $\mathrm{Al}$ concentrations in forage plants are believed to be more responsive to small changes in soil pH than is $\mathrm{Ti}$, but that must still be investigated.

Washing forage samples immediately after harvest reduces the amount of soil contamination, but washing is not always possible, nor is extensive washing desirable because of the potential loss of some endogenous minerals like $\mathbf{K}$. Techniques are available that allow correction for soil contamination and associated minerals. Corrections based on ash content (Thompson and Raven 1955) are of no value when studying grasses, because endogenous silicon 
dioxide $\left(\mathrm{SiO}_{2}\right)$ may be as high as $8 \%$ (Mayland unpublished data). The usefulness of the mineral dilution technique will depend on how closely the dust contamination on the plant sample resembles that of the soil sample used to determine Al, Fe, or Ti and the other minerals.

\section{Literature Cited}

Healy, W.B., P.C. Rankin, and H.M. Watts. 1974. Effect of soil contamination on the element composition of herbage. New Zealand J. Agr. Res. 17:59-61.

Hodgson, J.F. 1963. Chemistry of the micronutrient elements in soils. Advances Agron. 15:119-159.

Horvath, D.J. 1972. Availability of manganese and iron to plants and animals. Geological Soc. Amer. Bull. B3:451 462 .
Hyder, D.N., and F.A. Sneva. 1961. Fertilization on sagebrush bunchgrass range-A progress report. Oregon Agr. Exp. Sta. Misc. Pap. 115:1-36.

Metson, A.J., E.J. Gibson, J.L. Hunt, and W.M.H. Saunders. 1979. Seasonal variation in chemical composition of pasture. III. Silicon, aluminum, iron, zinc, copper, and manganese. New Zealand J. Agr. Res. 22:309-318.

Mitchell, R.L. 1960. Contamination problems in soil and plant analysis. J. Sci. Food Agr. 11:553-560.

Nes, P. 1975. A correction for soil contamination of herbage samples by dry ashing. New Zealand J. Agr. Res. 18:69-71.

Shacklette, H.T. 1980. Elements in fruits and vegetables from areas of commercial production in the conterminous United States. Geological Survey Professional Paper 1178. U.S. Govt. Printing Office, Washington, D.C. 20402.

Thompson, A., and A.M. Raven. 1955. Soil contamination of herbage samples. J. Sci. Food Agr. 6:768-777.

\section{Membership in the Society for Range Management. . .}

is open to those engoged in or interested in the study. manopement. or use of range ecosystems and the intelligent use of all range resources

includes research scientists. ranchers. oovernmental coency administrators and tectnical persomel. teachers. students. and people from the business community

provides members with two publications - one oriented to reseorch (Journal of Range Management) and the other oriented to practical resource manogement (Rangelands)
- Offers opportunities for face-to-face exchange of ideas at local, national, and intemational meetings of the Society.

Dues vary according to trpe of membership and geographical section. For application forms and additional information, contact the:

Execultive Secrelon

Soclety tor Range Manogement

2760 West Fitth Avenue

Denver. Colorodo 80204

(303) 571-0174

\begin{tabular}{|c|c|c|c|c|c|c|c|}
\hline \multirow[b]{2}{*}{ DUES SCHEDULE } & \multirow[b]{2}{*}{ Regular } & \multirow[b]{2}{*}{ Student } & \multirow[b]{2}{*}{ Sustaining } & \multirow[b]{2}{*}{ Emeritus } & \multirow[b]{2}{*}{ Institutional } & \multicolumn{2}{|c|}{ Family } \\
\hline & & & & & & $\begin{array}{l}\text { First } \\
\text { Member }\end{array}$ & $\begin{array}{c}\text { Each } \\
\text { Additional }\end{array}$ \\
\hline ARIZONA & 543.00 & S 22.00 & $\$ 64.00$ & $\$ 30.00$ & $\$ 203.00$ & $\mathbf{S 4 3 . 0 0}$. & $\ldots 23.00$ \\
\hline CALIFORNIA $\ldots \ldots \ldots \ldots \ldots$ & 45.00 & 23.00 & 68.00 & 30.00 & 225.00 & 45.00 & $\ldots 23.00$ \\
\hline COLORADO ............... & 42.00 & 22.00 & 62.00 & 29.00 & 202.00 & 42.00 & $\ldots \ldots \ldots 22,00$ \\
\hline 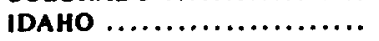 & 42.00 & 22.00 & 62.00 & 29.00 & 202.00 & 42.00 & $\ldots .22 .00$ \\
\hline KANSAS-OKLAHOMA ....... & 43.00 & 22.00 & 62.00 & 29.00 & 203.00 & 43.00 . & $\ldots .23 .00$ \\
\hline MEXICO $\ldots \ldots \ldots \ldots \ldots \ldots$ & 44.00 & 24.00 & 64.00 & 31.00 & 204.00 & $\mathbf{4 4 . 0 0}$ & $\ldots \ldots 24.00$ \\
\hline NEBRASKA $\ldots \ldots \ldots \ldots$ & 44.00 & 22.00 & 64.00 & 31.00 & 204.00 & 44.00 . & $\ldots 24.00$ \\
\hline NEVADA $\ldots \ldots \ldots \ldots \ldots \ldots$ & 42.00 & 22.00 & 62.00 & 29.00 & 202.00 & 42.00 & $\ldots 22.00$ \\
\hline NEW MEXICO ............. & 42.00 & 21.00 & 62.00 & 29.00 & 202.00 & 42.00 & $\ldots 2200$ \\
\hline NORTHERN GREAT PLAINS . & 43.00 & 23.00 & 63.00 & 30.00 & 203.00 & 43.00 & $\ldots 23.00$ \\
\hline INTERNATIONAL MNTN .... & 43.00 & 23.00 & 63.00 & 30.00 & 203.00 & 43.00 & .23 .00 \\
\hline PACIFIC NORTHWEST ...... & 45.00 & 25.00 & 65.00 & 32.00 & 205.00 & 45.00 . & $\ldots 25.00$ \\
\hline SOUTH DAKOTA ............. & 44.00 & 23.00 & 63.00 & 30.00 & 204.00 & 44.00 . & .24 .00 \\
\hline SOUTHERN $\ldots \ldots \ldots \ldots \ldots$ & 45.00 & 25.00 & 65.00 & 32.00 & 205.00 & 45.00 . & .. 25.00 \\
\hline FLORIDA $\ldots \ldots \ldots \ldots \ldots \ldots$ & 45.00 & 25.00 & 65.00 & 32.00 & 205.00 & 45.00 & .25 .00 \\
\hline TEXAS $\ldots \ldots \ldots \ldots \ldots \ldots \ldots$ & 43.00 & 21.50 & 63.00 & 30.00 & 203.00 & 43.00 & .23 .00 \\
\hline UTAH $\ldots \ldots \ldots \ldots \ldots \ldots \ldots \ldots$ & 43.00 & 23.00 & 63.00 & 30.00 & 203.00 & 43.00 & $\ldots 23.00$ \\
\hline WYOMING $\ldots \ldots \ldots \ldots \ldots$ & 43.00 & 22.00 & 63.00 & 30.00 & 203.00 & 43.00 . & $\ldots 23.00$ \\
\hline NATIONAL CAPITAL ........ & 42.00 & 22.00 & 62.00 & 29.00 & 202.00 & 42.00 . & $\ldots 22.00$ \\
\hline NORTH CENTRAL .... & 42.00 & 22.00 & 62.00 & 29.00 & 202.00 & $\mathbf{4 2 . 0 0}$ & .22 .00 \\
\hline UNSECTIONED ........ & $\mathbf{4 0 . 0 0}$ & 20.00 & 60.00 & 27.00 & 200.00 & 40.00 & $\ldots 20.00$ \\
\hline
\end{tabular}

